мережі пом'якшує внутрішню суперечність між прагненням до людей й страхом зближення у самотньої людини, дає можливість свідомо символічно заміщувати брак психологічної близькості.

Отже, основні чинники почуття самотності: екзистенційні (принципова неможливість повного злиття 3 іншим й самотнійсть як екзистенційна даність), глибинні (психотравми дитинства), ситуативні (вимушена ізоляція; свідомий вибір на користь життя соло).

\title{
Література:
}

1. Изард К. Психология эмоций / К. Изард; пер. с англ. К. Э. Изард. - СПб.: Питер, 1999. - 460 с.

2. Кляйненберг Э. Жизнь соло: новая социальная реальность. Москва : Альпина Пабликшер. 2014. 284 с.

3. Миллер А. Драма одаренного ребенка и поиск собственного «Я» / А. Миллер. - М.: Академический Проект, 2001. - 144 с.

4. Симада Н., Рафаэль С. Смешанный чувства: изучение эмоционального воздействия наших цифровых привычек. Мельбурн : Quadrille. 2019. 256 c.

5. Словарь психолога-практика / сост. С. Ю. Головин. - 2-е изд., перераб. и доп. - Мн.: Харвест, 2003. - 976 с.

DOI https://doi.org/10.30525/978-9934-588-80-8-1.11

\section{РОЛЬ ПСИХОЛОГА У ПРОЦЕСІ РЕАБІЛІТАЦІЇ ОСІБ ІЗ НАРКОТИЧНОЮ ТА АЛКОГОЛЬНОЮ ЗАЛЕЖНІСТЮ}

\author{
Козира П. В. \\ кандидат психологічних наук, \\ доиент кафедри психології факультету психологіі \\ Львівський державний університет внутрішніх справ \\ м. Львів, Україна
}

Діяльність психолога у закладах для реабілітації осіб із наркотичною та алкогольною залежністю можна порівняти із роботою педагога у закладах освіти, адже ,так само, як педагог повинен надати учням певні базові знання та навички, так і психолог повинен показати узалежненим інший шлях, ознайомити із основними принципами руху до тверезості, який після завершення процесу реабілітації кожен узалежнений повинен розвивати самотужки, у групах 3 іншими 
особами, які борються із залежністю, за допомогою рідних та близьких або за підтримки психолога.

Звісно, на цьому шляху існують певні нюанси.

Діти в школі навчаються 3 чистого листа на якому педагог впевненою рукою, «каліграфічно записує» знання, які поведуть у майбутнє. Натомість, психолог здобуває завдання «боротьби» із учнем, який так само, як і звичайний учень у школі свій листок отримав від педагога 3 каліграфічними записами, але в силу певних обставин, а саме: відсутністю батьківського виховання у процесі дорослішання, значного впливу вулиці та безлічі різних негативних аспектів, які здійснюють вплив у процесі дорослішання, на отриманому листку, поверх каліграфічно написаного, «розмалював» його певними карикатурами та текстами, засвоєними під впливом перелічених вище негативних факторів.

Інший аспект - це деградація особистості та примітивізація іiі потреб, яка провокується вживанням алкогольних та наркотичних речовин.

В особи, яка знаходиться в активній стадії вживання, так само, як і в учня, який навчається у випускних класах і має систематичні проблеми iз навчанням, поведінкою та конфліктує із педагогами, на фоні переліченого формується власна система цінностей, у якій немає місця середньостатистичним переживанням, таким як, вибір вищого навчального закладу, роздумів стосовно майбутньої професії та роботи. Існує лише сьогодення, а наступний день залишається незвіданим [1, с. 31].

Поряд із сумлінним педагогом, психолог намагається розгледіти «життєвий пробіл», який став рушійною силою, яка у подальшому призвела до залежності та разом із узалежненим пропрацювати отриманий досвід 3 метою не повернення до вживання у майбутньому, а набуття нових цінностей та віднайденню давно забутих старих, отриманню назад своїх життевих ролей та обов'язків, які в силу залежності, перебрали на себе інші члени сім'ї, рідні та близькі, для яких особа узалежнена є батьком, сином, чоловіком, братом, другом, робітником чи товаришем.

Це один із найскладніших аспектів роботи з особами, які залежні від алкоголю чи наркотичних речовин або того та іншого. Оскільки вони свято вірять у те, що перелічені вище цінності, життєві ролі у них повністю збережені, навіть більше, під впливом вживання є суттєво кращими та продуктивнішими і не вносять жодного деструктивну як у власне життя так і в життя оточуючих.

У таких осіб психолог часто асоціюється із суворим педагогом, який забороняє на уроці під назвою «власне життя» гратись улюбленою 
грою і намагається донести певні знання, які в очах узалежненого $\epsilon$ абсолютно непотрібними i жодним чином не вписуються у його систему цінностей та ритму життя загалом.

Які ж способи корекції та повернення до життя без вживання?

Схожі на ті, що використовує педагог в освітньому процесі, а саме: вказування на помилки учня, піднесення, як приклад учнів 3 кращою успішністю, розмова із батьками.

Лише в процесі реабілітації вказані вище способи носять інше забарвлення i мають більш широке значення: 3 узалежненим пропрацьовується життєвий досвід, 3 метою пошуку роздоріжжя, яке призвело до вживання, а також здійснюється пошук можливих джерел задоволення власних життєвих потреб, без повернення до вживання.

Процес реабілітації в основному передбачає групову роботу, у якій завжди знаходяться учасники, які ставляться до життя у тверезості досить серйозно, проводять значну роботу над собою та у боротьбі із залежністю. Такі люди є хорошим поштовхом до руху вперед осіб, які сумніваються стосовно того чи варто виринати із тенет залежності i роблять кроки на шляху до тверезості неохоче та невпевнено.

У кожного узалежненого $є$ людина, для якої він $є$ рідним та близьким, в основному це батьки, дружини, чоловіки, діти - це люди, які намагаються втримати людину залежну на поверхні життя незважаючи ні на що і це $є$ доволі двозначним, оскільки 3 однієї сторони - такі люди намагаються надати певні ресурси для людини 3 адикцією у боротьбі із хворобою, а 3 іншого боку - можуть потурати узалежненому з метою частково убезпечити його у вживанні, зокрема, це проявляється у наданні певних коштів для придбання наркотичних чи алкогольних речовин, а також, як вже було зазначено вище, перебирання життєвих ролей та обов'язків особи із адикцією на себе. Тому робота із рідними та близькими має також важливе значення на шляху до тверезості, адже саме до цих людей особа, після реабілітації, повертається та вступає у взаємодію, ці люди також повинні розуміти нюанси ресоціалізації узалежнених, а також вміти розпізнати симптоми рецидиву $з$ метою недопущення повернення до вживання [2, с. 5].

Звісно, «левова частка» роботи лежить, в першу чергу, на самому узалежненому, адже скільки б не шукати причин потрапляння у залежність, скільки б не наголошувати на досягненнях колег на шляху боротьби, скільки б рідні та близькі не докладали зусиль для того, щоб вберегти від вживання, без власного бажання особи, яка проходить реабілітацію, щось змінювати у власному житті, ці благі наміри мають дуже малі шанси на успіх.

На цьому етапі, так само, як і в учнів шкіл, злий жарт може зіграти звичайна лінь, яка почне вибудовувати певні страхи до пізнання нового 48 
та зароджувати банальну думку стосовно недоцільності ведення тверезого способу життя.

Адже, саме слово «боротьба» передбачає певну дію, а у випадку із залежністю це особливо актуально, оскільки зі слів самих узалежнених: «наркотик чи алкоголь вміють чекати». Тобто, коли людина перестає працювати над собою, розвиватись, прагнути пізнавати щось нове, а у випадку із особами залежними дотримуватись «програми одного дня», яка передбачає щоденні планування власного життя у якому не знайдеться місця наркотику чи алкоголю, коли особа перестає самому собі обгрунтовувати доцільність перебування у тверезості, перестає аналізувати втрати, які вона отримає при поверненні у вживання - все може обернутись зривом та поверненням до попередньої пагубної звички.

На жаль, значна частина осіб із наркотичною чи алкогольною залежністю потрапляє на реабілітацію з відсутністю бажання будь-що змінювати у власному житті і тут завдання психолога, так само, як $\mathrm{i}$ сумлінного педагога, полягає у необхідності привити бажання «узалежненому учню» до навчання або хоча б до можливості задуматись про позитивні сторони життя без вживання.

Частина осіб, які потрапляють на реабілітацію із значним опором до роботи над своєю залежністю, саме під впливом перелічених вище факторів, а також за допомогою інших узалежнених, задумуються над можливістю обрати для себе інший шлях і на цьому етапі вони також отримують перешкоду, яку необхідно прийняти і навчитись 3 нею жити та боротись - це почуття відповідальності або докори сумління.

Крім передачі ролей та обов'язків особа залежна часто опиняється перед вибором витрачання власних матеріальних цінностей, а згодом матеріальних цінностей рідних та близьких 3 метою задоволення потреби в алкоголі чи наркотиках.

У подальшому до витрат також можна приписати погіршення авторитету рідних та близьких, а також накладання на них соціальних штампів 3 боку оточуючих в силу залежності близької людини, оскільки рідним дуже часто доводиться вирішувати проблеми узалежненого спричинені вживанням алкогольних та наркотичних речовин, до них можна віднести проблеми із колекторськими фірмами, правоохоронними органами та так званими «друзями» самого узалежненого.

Перелічений вище тягар падає на плечі узалежненого після певного часу перебування на реабілітації, в той момент, коли дія наркотиків чи алкоголю спадає і людина виринає у тверезе життя та постає перед плодами своєї діяльності [3, с. 198]. 
В особи з адикцією при бажанні роботи над собою, так само як і в школяра, існує безліч питань, переживань та почуття невпевненості в собі, і завдання психолога тотожне роботі педагога, зокрема - це допомога у пошуку відповідей на питання, які є важливими у житті людини.

\title{
Література:
}

1. Громадська спілка «Міжнародна антинаркотична асоціація». Комплексна програма реабілітації осіб 3 хімічної та нехімічної залежності. - Київ. - 2014. - 173 с.

2. Постанова Кабінету міністрів України від 04.10.2017 № 741 «Про затвердження типових положень про заклади соціальної підтримки сімей, дітей та молоді» - Режим доступу: https://zakon.rada.gov.ua/laws/show/741-2017-\%D0\%BF\#Text

3. Відновлення. Звільнення від наших залежностей / Расселл Бренд; пер. $з$ англ. М. Коваленко. - Дніпро: Моноліт, 2020. 304 с.

DOI https://doi.org/10.30525/978-9934-588-80-8-1.12

\section{СУЧАСНІ ТЕНДЕНЦЇ̈ РОЗВИТКУ ПРАКТИЧНОЇ ПСИХОЛОГІЇ НА СХОДІ УКРАЇНІ В УМОВАХ ЗБРОЙНОГО КОНФЛІКТУ}

\author{
Кравцова О. К. \\ аспірантка кафедри психології управління \\ Центральний інститут післядипломної освіти \\ ДВНЗ «Університет менеджменту освіти» \\ м. Київ, Украӥна
}

32014 року мешканці сходу України намагаються вижити в умовах збройного конфлікту, дехто втратив близьких, хтось втратив житло, роботу та не має грошей на прожиття. Хтось все ще живе в цих нелюдських умовах, а хтось поїхав втративши та кинувши все, за офіційними даними в Україні близько 1,5 млн. внутрішніх переселенців [3]. Україна поділилась на підконтрольну уряду та з'явилась непідконтрольна частина території, протяжність лінії розмежування 457 км, на відстані 20 км залишилися проживати близько 0,8 млн. чоловік, на відстані 0-5км живуть 0,2 млн. Сукупні наслідки психологічної травми, страх перед новою ескалацією конфлікту, щоденний ризик отримання травм та обмеження свободи переміщення 